\title{
ON INTRODUCING GODS TO ATHENS: AN ALTERNATIVE READING OF ACTS 17:18-20
}

\author{
Bruce W. Winter
}

\section{Summary}

Acts 17:18 records that some Athenians perceived Paul to be a 'herald of strange gods' because of his evangelistic activity in the Agora. This essay examines the conventions surrounding $a$ 'herald's' official introduction of new deities into the Athenian Pantheon, throwing further light on Paul's Areopagus address and suggesting an alternative translation of Acts 17:19-20.

\section{Introduction}

In a recent book, Introducing New Gods: The Politics of Athenian Religion, Professor R. Garland discusses the conventions for introducing new gods to Athens and provides examples from the beginnings of Athenian religion to 399 BC. ${ }^{1}$ Garland notes:

A convenient forum in which to advertise the benefits of a new god and hence to drum up popular support would have been a public meeting place such as the Agora, the civic, administrative and commercial heart of the city and a popular venue for all those who wished to exchange ideas. ${ }^{2}$

He then cites Acts 17:17 as evidence, and comments that 'Paul argued... in the Agora every day... Subsequently the apostle was invited to present his case more formally on the hill known as the Areopagus-or alternatively before the administrative body of that name.'3

\footnotetext{
${ }^{1}$ London: Duckworth, 1992. In the ancient authors and general indexes there are no references to Acts or Paul, and therefore his passing references appear not to have been noticed in Acts 17 studies.

${ }^{2}$ Garland, Introducing New Gods, 18-19.

${ }^{3}$ Garland, Introducing New Gods, 19.
} 
Because of the period Garland covers in his book, he does not specifically explore whether or not the Athenians saw Paul to be promoting new gods who might be incorporated into their Pantheon. The purpose of this essay is to examine the setting of Acts 17:17-20 and to suggest an alternative reading of the passage. This will be done by (1) rehearsing briefly the conventions for introducing new gods into ancient Athens, and considering the success or failure of a cause in doing so, (2) reporting first-century $\mathrm{AD}$ examples of important gods or goddesses being introduced into that city, thereby extending the discussion beyond the period covered by Garland, (3) examining in some detail the text of Acts to show that some Athenians perceived Paul to be seeking the acceptance of new gods by the city and the possible assimilation into the Pantheon, which accounts for the preliminary explanation given to him in Acts 17:19-20, (4) providing fresh insights into aspects of the summary of his speech in the light of these findings, and (5) explaining the composition of the audience.

This essay is not arguing, as T.D. Barnes did in his important contribution to the discussion of Acts 17, that Paul seems to have been put on trial in Athens. Barnes concluded that this theory 'possesses intrinsic plausibility', although he believed that it was a 'clearly impossible task of providing proof positive'. ${ }^{4}$ Rather, this essay seeks to show that the Council of the Areopagus, together with the Council of 600 and the Demos ('the People'), sanctioned the official introduction of new gods to Athens. This involved the Areopagus engaging in an evaluation of the cult to see if these were genuine gods being promoted by the particular herald. This was not an adversarial procedure or a trial, as Barnes suggests. It sought only to ascertain several matters: Had there really been an epiphany of the divinity? Was official recognition to be given? What divine honours and statues would be appropriate? When would the annual official feast day be?

4T.D. Barnes, 'An Apostle on Trial' JTS XX (1969) 407-19, citing 419. This essay does not denigrate the importance of Barnes' crucial piece of work where he gathered primary sources which clarify the constitutional position of the Areopagus or what 'before the Areopagus' might mean. 


\section{Introducing New Gods to Ancient Athens}

As Garland notes:

Athens not only took a significant part in promoting new cults throughout the Greek world, but also gave them a prominence which greatly facilitated their subsequent elevation to the rank of Panhellenic deities. 5

In this 'land most dear to the gods', 6 therefore, the approval or disapproval of new gods being added to the Athenian Pantheon continued to set the precedent for other Greek cities. Diodorus Siculus records that it was the Athenians who first honoured Heracles as a god, after which point the worship of Heracles spread further afield: 'they induced for all the Greeks and then all men in the inhabited world to worship Heracles as a god' (4.39.1). However, as Garland observes:

the acceptance of a new deity was by no means automatic... Athens... refused Leto permission to give birth to Apollo on their soil... As a metaphor for the rough road which had to be travelled by supporters of a new cult seeking a permanent home for their god, the hymn [The Homeric Hymn to Delian Apollo] bears eloquent witness to the strength of opposition which even the cult of a major Olympian deity was believed to have faced in its infancy... It is regrettable that the Athenians did not keep statistics on the acceptance-rate of petitioning deities. ${ }^{7}$

Nonetheless, there are a number of examples of new gods making it into the Pantheon in the period up to $399 \mathrm{BC} .8$ There is little extant evidence which could identify the promoters or heralds of new cults. Nothing is recorded of Pegasos of Eleutherai who brought the cult of Dionysos to Athens, of Pheidippides who championed Pan, or of Telemachos who installed Ascleios beside the Acropolis. ${ }^{9}$ How they secured

\footnotetext{
${ }^{5}$ Garland, Introducing New Gods, 8.

${ }^{6}$ Aeschylus, Eumenides, 869.

${ }^{7}$ Garland, Introducing New Gods, 10.

${ }^{8}$ Garland, Introducing New Gods, ch. 1-7.

${ }^{9}$ Garland, Introducing New Gods, 18.
} 
grass roots support for their cult is also not generally known, except in the case of the cult of the Mother of the Gods where it was done by itinerants known as 'beggars of the Mother'. ${ }^{10}$

At what point did the propagators of the cult formally request that official recognition be given to their god and how would they have secured such recognition? It is known that from c. $460 \mathrm{BC}$, the official authorisation of new deities lay primarily 'in the hands of the Boule and Demos, which alone had the right to recommend and implement religious change.'11 Garland acknowledges that we have no record of arguments which might be put forward to persuade the Council of the Areopagus to place this item on the agenda for the formal meeting of the Demos and to decide that a petitioning cult already enjoyed sufficient grass-roots support among the populace to justify putting its claims to a democratic vote.'12 However it is certain that those who secured the introduction of a cult had to have substantial means, for they had to buy consecrated ground (temenos) and build an altar for a sacrifice. There was also the requirement to endow an annual feast.13

What effect the introduction of new gods had on an individual is perhaps difficult to gauge. We do know that, at the grass roots level, Alkiphron complains that his wife has become 'urbanised' and is 'introducing to us new gods in addition to the many we have already', although he notes that 'because of their number most have slipped my memory.' These comments may mask a complaint concerning her change of lifestyle, and suggest that her social mobility has been accompanied by the veneration of new gods which she introduced into the household, with some measure of reluctance or indifference on the part of her husband. ${ }^{14}$ As a farmer he was not among the urban élite of Athens. We can speculate that, in terms of Athenian life, the addition of new divinities meant the neglect of other gods. We do know that it involved new sanctuaries and new feast days.

\footnotetext{
10Garland, Introducing New Gods, 18.

11Garland, Introducing New Gods, 19.

${ }^{12}$ Garland, Introducing New Gods, 18.

13Garland, Introducing New Gods, 21.

${ }^{14}$ Letters to Farmers, 2.8.1-2.
} 


\section{Introducing First-century Gods to Athens}

Significant politico-religious changes occurred in Athens with the coming of Rome to the East. For example, 'the Panathenaia was renamed Antonaia and dedicated to him [Anthony] as a god ( $\theta \varepsilon$ ós).' More importantly, there was extremely rapid growth of the imperial cult in the East from the time of Augustus onwards. ${ }^{15}$ Not only deceased but also reigning emperors were deified, and sometimes this included wives and members of their families. Nero and his wife were added to the 'traditional gods' in the East. ${ }^{16}$ In Athens itself c. 18-37 AD during Tiberius' reign, Antonia Augusta, the famous grandmother of the emperor Claudius, was deified as 'goddess

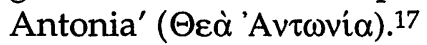

Although Athens had traditionally set the trend in the introduction of new gods for the whole of Macedonia and Achaea, she was not exempt from the impact these imperial gods were to have on her political/religious life. She may have maintained vestiges of her primacy, since Pausanias records in the following century that Hadrian's many temples throughout the empire were inscribed on the Pantheon of Athens (1.5.5). However, in the East she no longer held the role of deciding whether or not these imperial gods should be honoured in Greece.

What evidence do we have of the procedures for introducing new gods in the East? Nero made a famous and unprecedented move when he granted exemption to the provinces of Macedonia and Achaia from the tax which had originally been imposed at the time of the Roman 'conquest'. This provides an example of the convention surrounding the incorporation of Nero and his wife, Messallina, into the traditional gods of its cities. An inscription records not only Nero's speech and the edict delivered at Corinth on 29th November, AD 67, but also the decree of the city of Acraephia:

${ }^{15}$ D. Fishwick, The Imperial Cult in the Latin West (Leiden: Brill, 1987) I. 48. For a discussion of this growth see his Vol. I.

${ }^{16} S_{I G}{ }^{3}, 814$.

17IG, II/III ${ }^{2}$ 5095, N. Kokkinos, Antonia Augusta: Portrait of a Great Roman Lady (London: Routledge, 1992) 98. 
the high-priest of Augusti for life and of Nero... Epaminondas proclaimed, having submitted to the Council and the Demos beforehand... it had been decided by the magistrates and councillors and people to worship him [Nero] at the existing altar dedicated to Zeus the Saviour, and to inscribe upon it 'To Zeus the Liberator, Nero forever' and to erect statues of Nero Zeus the Liberator and the goddess Augusta Messallina... to share with our ancestral gods. ${ }^{18}$

This proposal had been formally put by Epaminondas, a priest of Augustus, to the Council on the grounds that Nero, by his actions, had shown himself to be 'Zeus, the Liberator, the one and only greatest imperator of our times, friend of the Greeks.' His actions had restored freedom to Greece 'which none of the previous Augusti gave us' (ll. 40-41, 45-46). The ruling body of the city, 'the Council', had approved and placed its resolution before the Demos. The inscription records that the magistrates, as well as the councillors and the Demos, resolved to worship Nero and agreed to erect statues so that he and his wife, as new gods, would share the temple of Ptoian Apollo with the traditional gods. In order to show the 'equality' that Nero and his wife now had with the gods, it was further resolved that the inscription recording this decree would be placed 'on a column set beside Zeus the Saviour in the market-place and on the temple of Ptolian Apollo' (ll. 55-57). This act re-enforced their declaration that Nero was truly 'Zeus, the Liberator'.

If the Council and the Demos were the ones who passed the decree to worship Nero in the city of Acraephia, we must inquire as to which body would be responsible for the incorporation of the reigning emperors into the Athenian Pantheon.

The Council and the Demos honoured Drusus Caesar, son of a

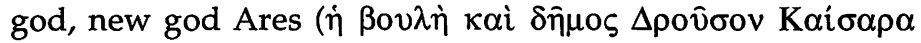

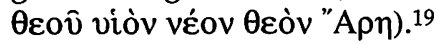

Cicero explains which Athenian Council was meant: 'when one says "the Athenian state is ruled by the council," the words "of

${ }^{18}$ SIG $^{3}, 814$ ll. 29-30, 44-51 (28th Nov., AD 67).

${ }^{19} I G, \mathrm{II}^{2} 3257$. 
the Areopagus" are omitted.'20 A Neronean inscription records the full legal entities involved in such moves.

Tiberius Claudius Herodes of Marathon, priest and highpriest of Nero Caesar Augustus for life, made this dedication to Dionysius [Zeus] the Liberator and Nero Claudius Caesar Augustus Germanicus and the Council of the Areopagus and the Council of the 600 and the people of Athenians from his own resources when Tiberius Claudius Novius was general of the hoplites for the seventh time. ${ }^{21}$

Although dedicated to Nero, this inscription is likewise linked with Dionysius, the Liberator, 22 and is dated not later than $60 / 61$ AD. 23 It is also dedicated to the Council of the Areopagus. The person who made the dedication was also Nero's priest and high-priest, the benefactor, Tiberius Claudius Novius, who occupied the honorary post of hoplite general on seven occasions. ${ }^{24}$ In Acraephia, it was the magistrates who join the Council and the Demos in the resolution. The difference in Athenian inscriptions was that 'the Council of the Areopagus, and the Council of 600 and the Demos' were named as the traditional instruments of government. 25

Julia divine Augusta Providence; the Council of the Areopagus and the Council of the 600 and the Demos; dedicated by Dionysius... from his own resources, when the agoranomi were the same Dionysius, of Marathon, and Quintus Naevius Rufus, of Melite. ${ }^{26}$

${ }^{20}$ Cicero, De natura deorum II. 74.

$21 I G, \mathrm{II}^{2} 3182$.

22In Athens $I G, \mathrm{II} / \mathrm{III}^{2} 3278$ Nero is designated as the new Apollo. 'To Imperator Nero Caesar Augustus, New Apollo'.

${ }^{23}$ For dating before AD 60/61, see J.H. Oliver, The Athenian Expounders of the Sacred and Ancestral Law (Baltimore: Johns Hopkins, 1950) 82-83.

${ }^{24} \mathrm{On}$ the role of the High Priest of the Imperial Cult, see Oliver, The Athenian Expounders, ch. 5.

25It would not be without precedent that a statue or statues represented the Council of the Areopagus, the Council of 600 and the Demos, as was the case in Ephesus, G.M. Rogers, The Sacred Identity of Ephesos: Foundation Myths of a Roman City (London and New York: Routledge, 1991) 83.

${ }^{26} I_{G}, I^{2} 3238$. 
Where were these imperial gods placed? In keeping with other cities, civic space had been transformed in order to accommodate the imperial cult. ${ }^{27}$ As S.R.F. Price observes, the pre-existing architecture needed to be modified, as is clear 'in Athens when the portico of Zeus on the main square was altered, probably in the Augustan age, by the addition of a double room built out through the rear wall of the portico.'28 An inscription on the pedestal of a statue erected after $40 \mathrm{AD}$ records 'Julia Augusta Bouleae (ßov $\lambda \alpha i \alpha v),{ }^{29}$ mother of Tiberius Augustus, the council of the Areopagus ( $\dot{\eta} \beta o v \lambda \dot{\eta} \dot{\eta} \dot{\varepsilon} \xi$ 'Apeiov $\left.\pi \alpha \gamma_{0 v}^{\prime}\right)^{\prime}{ }^{30}$ This statue to Julia Augusta was of the deceased Livia, the mother of Tiberius. It shows that another goddess has been 'added' in Athens and placed in a noted public place, i.e., in the Council chamber.

How were these new imperial gods and goddesses, or indeed any deity, introduced officially into Athens in the first century, and how was a cult set up to worship them?31 In contrast to other cities in the East which authorised their introduction through the Council and the Demos, Athens used its own peculiar instruments of government; first-century official inscriptions refer to 'The Council of the Areopagus and the Council of the 600 and the Demos' ( $\dot{\eta}$ ßov $\lambda \dot{\eta} \dot{\eta} \dot{\varepsilon} \xi$ 'Apriov $\pi \alpha$ ' undertook his role relation to the Areopagus. ${ }^{33}$ It is suggested that he, together with the Council, would have been responsible for receiving the name of the member of the

27S. Mitchell, 'The Imperial Cult', in The Celts and the Impact of Roman Rule (Anatolia: Land, Men, and Gods in Asia Minor; Oxford: Clarendon, 1993) Vol. I, 102-7.

28S.R.F. Price, Rituals and Power: The Roman Imperial Cult in Asia Minor (Cambridge: CUP, 1984) 141-42.

${ }^{29}$ The term $\beta$ ovidí $\alpha$ was an epitaph used of an imperial goddess in the Council chamber, e.g. Aeschines, 'On the Embassy', 2.45, IG, II² 912.

${ }^{30}$ Ann. ép. (1938) 83.

31S.E. Alcock designates the process as one of assimilation; Graecia Capta: The Landscapes of Roman Greece (Cambridge: CUP, 1993) 195.

${ }^{32}$ E.g., OGIS 428, SEG xxi, 742, IG II/ $\mathrm{III}^{2} 3182$.

${ }^{33} \mathrm{On}$ role of Areopagus and the $\alpha \rho \chi \omega v$, see D.J. Geagan, The Athenian Constitution after Sulla (Hesperia Supplement 12; Princeton: American School at Athens, 1967) xiif., $24 \mathrm{ff}$. 
imperial family whose divinity was to be recognised, and for placing the item on the agenda of an Ekklesia for approval by the Demos. The imperial high-priest may have been the person who moved the motion, as was the case in Acraephia, but the Council of the Areopagus would have been the body responsible for initiating action for the assimilation of the new god.

Barnes raises the issue of the role of the Council of the Areopagus and of the Areopagus itself, when he writes:

the Areopagus seems to be the effective government of Roman Athens and its chief court. As such, like the imperial Senate in Rome, it could interfere in any aspect of corporate life-education, philosophical lectures, public morality, foreign cults. ${ }^{34}$

Yet in the same paragraph he argues that the success of the Areopagus lay its prestige and not its power, citing as an example its success in persuading Cratippus to remain and teach in Athens. Barnes then curiously states that 'there is no need to suppose that the Areopagus had special "surveillance over the introduction of foreign divinities" in order to interest itself in Paul', and adds in a footnote 'As appears to be implied by Geagan'. His citing of Geagan is somewhat misleading, however, for Geagan himself stated categorically that the 'account of Paul's speech before the Areopagus illustrates its surveillance over the introduction of foreign divinities.'35 Barnes noted and used Geagan's work as an important treatment of the constitution of Athens after Sulla (138-78 BC). The former's view, that the Areopagus had no interest in Paul's role as a herald of new gods, has to be rejected in the light of Acts 17:19-20, which says that Paul appeared to some to be a herald.

It needs to be noted that even if it had not been the role of the Areopagus to examine those who sought to introduce new gods to Athens prior to the Roman period, it certainly would have fallen to the governing body of Athens to be part of

${ }^{34}$ Barnes, 'An Apostle on Trial', 413.

${ }^{35}$ Geagan, The Athenian Constitution after Sulla, citation 50. 
the procedure of the deification of the reigning emperor and selected members of his family, living or deceased. This was the case in other cities. Officials moved resolutions by which members of the imperial family were included with the traditional gods, and from the well-attested epigraphic evidence this was also a responsibility of the Council of the Areopagus in the government of Athens in the first century. ${ }^{36}$

\section{The Athenians' Response to Paul in Acts 17:16-21}

What was Paul perceived to be doing in Athens? How did some of his hearers react, and why? The text indicates that there were two assessments of what he was doing there. According to Acts 17:17, some described Paul pejoratively as 'a charlatan',37 and others said, 'He appears to be a herald of

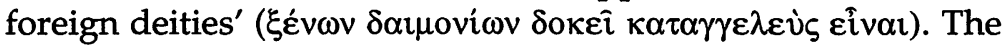
term $\kappa \alpha \tau \alpha \gamma \gamma \varepsilon \lambda \varepsilon v$ s was used in the time of Augustus of 'a herald' of the imperial cult, and also of the herald of the Areopagus who appeared on the archon-list and possessed the seal of Athens. 38 This would suggest that Paul was seen by his hearers to be announcing new deities to the Athenians. This is evident also from their view that Paul 'was proclaiming "Jesus

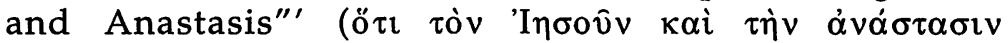
$\varepsilon \cup ่ \eta \gamma \gamma \varepsilon \lambda i \zeta \varepsilon \tau 0){ }^{39}$

36While it has become customary among New Testament scholars to see it having very little power, the evidence of its very substantial role in the judicial as well as the civic affairs of Athens is well attested in the first century. See D.W.J. Gill, 'Achaia' in D.W.J. Gill and C. Gempf (eds.), The Book of Acts in its Graeco-Roman Setting (Grand Rapids/Carlisle: Eerdmans/Paternoster, 1994) 447. On its earlier role, see R.W. Wallace, The Areopagus Council to 307 BC (Baltimore: Johns Hopkins UP, 1985).

37I.e., a rag-bag collector of scraps of learning.

${ }^{38}$ On the use of this term, see OGIS 456, which is a Mytilenean decree in honour of divine Augustus, and discussion in D. Fishwick, The Imperial Cult, I.1, 172. On the herald of the Areopagus, see $I G \mathrm{II}^{2} /$ iv 83, and discussion in Geagan, The Athenian Constitution after Sulla, xiif., $24 \mathrm{ff}$.

39F.F. Bruce, The Acts of the Apostles: Greek Text with Introduction and Commentary (Leicester/Grand Rapids: IVP/Eerdmans, 19903) 377: 'they might have thought that Anastasis was a new-fangled goddess'. Contra K.L. McKay, 'Foreign Gods identified in Acts 17:18?', TynB 45.2 (1994) 411 who argues that 'Paul would not have introduced the idea of 
What action did these Athenians take on the basis of this perception? The following verse states that 'they took

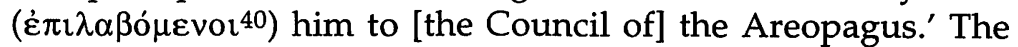
Western text prefixes the sentence with 'after some days' and then adds that they were 'inquiring' as to his teaching. The statement 'after some days' could suggest that this inquiring occurred at a formal meeting of the Council. However, even if this variant is rejected, it seems likely from what we have seen that they brought Paul to the Areopagus to inquire of him further, since some of his hearers had cast him in the role of a herald of foreign deities.

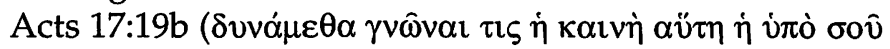

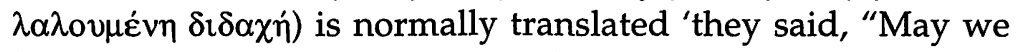
know what this new doctrine is that you are propounding?"' However, another rendering of the Greek is possible when these words are read within the semantic field of politeia.41 $\delta v v \alpha \dot{\mu} \mu \varepsilon \alpha$ can be translated as a present indicative, 'we have the power'. Justification for this meaning is found, for example, in P.Oxy. 899 (AD 200) which is a legal petition, written by a lawyer. In it, a decree of Tiberius Alexander is cited and the judgement of a court handed down on the basis of that degree and another ruling. It is ruled (l.31) that the petitioner 'has the power ( $\delta \dot{v} v \alpha \alpha \mathrm{t})$ [the legal right] to be released', in contrast to

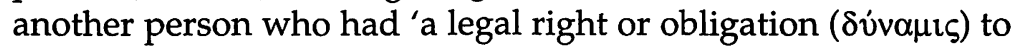
cultivate' (l. 9). That would suggest that those before whom Paul is brought possessed the right to question him, in parallel

resurrection... by means of the abstract noun, $\dot{\alpha}$ ó $\sigma \tau \alpha \sigma \iota \varsigma^{\prime}$ since Paul does not use it thus elsewhere in his letters and was unlikely to have used in an abstract form here. It is difficult to escape the implications of the reference to foreign 'gods' followed by ö $\tau$.

${ }^{40}$ The verb 'take' or 'take hold' gives the impression of 'seize' or 'arrest' (cf. Acts 21:33) but the subsequent discussion in vv. 19-20 suggests that another meaning is appropriate, i.e., 'take'.

41The word itself did not mean 'politics' in the first century but referred to all that occurred beyond the confines of the household. The dichotomy for life in the city was drawn between 'ones own' and 'politeia'. For discussion of the term, see C. Meier, The Greek Discovery of Politics (ET Harvard: Harvard UP, 1990) 13ff. For its application to the New Testament, see my Seek the Welfare of the City: Christians as Benefactors and Citizens (Grand Rapids/Carlisle: Eerdmans/Paternoster, 1994). 
with the example from P.Oxy. 899. There is, however, sufficient literary and non-literary evidence to render $\delta v v \alpha \dot{\alpha} \mu \theta \alpha$ as 'we have power or authority' and to conclude $\delta v v \alpha \dot{\mu} \mu \varepsilon \theta \alpha$ was a synonym for the term normally used, viz. "̌ $\xi \varepsilon \sigma \tau \imath v .42$

$\gamma \nu \hat{\omega} v \alpha \mathrm{r}$ can also be translated as 'to form a judgement'. Herodotus records that an agreement was sworn and they adjudged ("z $\gamma v \omega \sigma \alpha v) . . . '$ (1.74). Similarly, he writes elsewhere that the Lacedaemonians assembled a court and gave a judgement (" $\left.\gamma^{\prime} \nu \omega \sigma \alpha v, 6.85\right)$. Other references could also be given to support the translation 'determine' or 'decree'.43 Good grounds exist, then, for arguing that, in this verse, Paul was not being asked to provide an explanation. Instead the Council was informing him initially 'we possess the legal right to judge what this new teaching is that is being spoken by you.' 44

They explain their reason for this assessment: 'for you

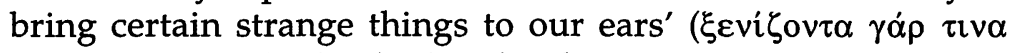

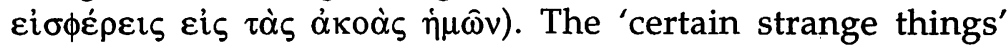
( $\xi \varepsilon v i \zeta o v \tau \alpha \tau \imath v \alpha$ ) is a reference to foreign deities. The neuter construction would indicate the caution with which the content of Paul's proclamation is treated, for they would not concede that these 'things' were deities before examination.

The following sentence also suggests their guardedness concerning the attribution of divinity which Paul is seen to be heralding in 17:18; for this reason, the neuter 'these' ( $\tau \alpha \hat{v} \tau \alpha)$ is used for 'gods' in 17:20b. The usual translation of ßov $\lambda$ ó $\mu \varepsilon \theta \alpha$

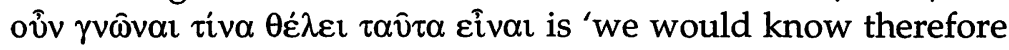
what these things mean', but a different interpretation is suggested here. Literary sources demonstrate that the verb $\theta \dot{\varepsilon} \lambda \omega$ is best rendered 'maintain', 'hold', or 'claim' when it is followed by the accusative and the infinitive, as in Acts 17:20b.45 Pausanias provides two comparable examples-'they

\footnotetext{
${ }^{42}$ Bruce, The Acts of the Apostles: Greek Text, 377 made the observation, which he left undeveloped, that Attic Greek would prefer $\varepsilon \xi \xi \sigma \tau \imath v$ here to the use of $\delta v v \alpha \dot{\mu} \mu \varepsilon \theta \alpha$.

${ }^{43}$ Liddell and Scott also cite Isocrates 17.6 and Herodotus 9.3.

${ }^{44} \mathrm{Cf}$. Dio Chrysostom, Or. 14:24: 'we shall not be able to judge ( $\delta v v \eta \sigma o ́ \mu \varepsilon \theta \alpha$ $\gamma v \hat{\omega} v \alpha \mathrm{l})$ between the free man and the slave', although in this case it relates more to a matter of outward appearance.

${ }^{45}$ See Liddell and Scott \#7 for this meaning and supporting evidence.
} 
are claiming that they are themselves Arcadians' ('Apкódec

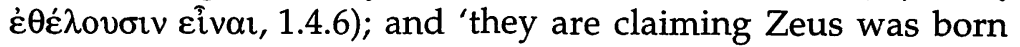

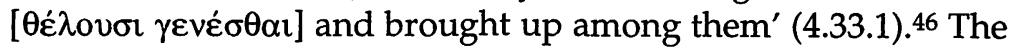
verb followed by the same construction can also mean 'to decree' or 'command'- 'He decreed the danger of the case to

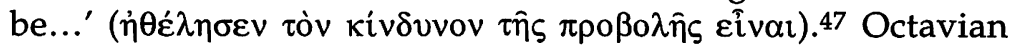
wrote a private letter where the imperial wish carries the same

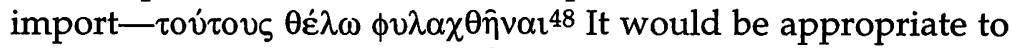

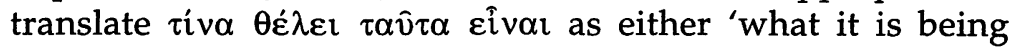
claimed these things (i.e., gods) are' or 'being decreed', if Paul was seen as a herald of possible new divinities. ${ }^{49}$ On the basis of the meaning of $\gamma v \omega \hat{v} \alpha \mathrm{l}$ in $v .19$, the sentence could then read 'We therefore wish to make a judgement ( $\gamma \nu \bar{\omega} v \alpha \mathrm{l})$ on what it is being claimed (or decreed) these things are.'

The tone of the sentences is polite, for this is not a prosecution; instead, it is an initial meeting of Council members with Paul, after it had been reported that he was possibly the herald of new divinities. They would know that, if he gained popular support in Athens, he might secure a rightful place for his deities in the Athenian Pantheon. Their courteousness is also in keeping with the fact that the herald would normally be a person of status and financial standing. The introduction of a new cult involved the herald buying a site, constructing an altar for sacrifices, providing a substantial benefaction for at least an annual dinner to honour the gods, and possibly providing support for cultic officials. The text as a whole reflects a sensitivity to an issue that was not merely of religious but also of political import, if indeed such a dichotomy could ever have validity in Athenian life.

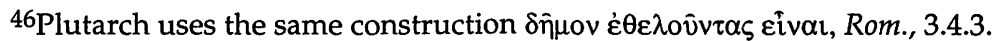
${ }^{47}$ CPR 20 l. 17 (3rd century AD).

48 J. Reynolds, Aphrodisias and Rome (JRS Monographs 1; London: The Society for the Promotion of Roman Studies, 1982) 10 l. 4 (BC 39-38). The following line confirms that Augustus is decreeing what must be done.

${ }^{49} \mathrm{Cf}$. Acts 2:12 where the speakers determine the meaning of the verb $\theta \dot{\varepsilon} \lambda \varepsilon \imath$ : 'they were all amazed and were perplexed, saying one to another

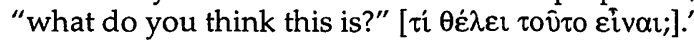




\section{The Athenians' Perception of Paul's Speech}

Consideration needs to be given to how the case presented above throws light on Luke's summary of the Areopagus address. After the captatio benevolentiae of 17:23a, there would be an element of uncertainty after hearing Paul's exordium. He was not technically heralding new divinities to Athens. Rather he was declaring the nature of the divinity whom they had already honoured or worshipped ( $\varepsilon \dot{\sigma} \sigma \varepsilon \beta \varepsilon i \tau \varepsilon)$. The proof that they had been doing this is to be found in the Athenian inscription that they themselves had erected, "To an unknown god' ('A $\gamma v \omega \sigma \tau \omega$ $\theta \varepsilon \omega \hat{)})$. The Stoics and Epicureans would have had no difficulty with the use of the singular 'god', for in one sentence they used the singular and plural interchangeably. For example, Diogenes Laertius speaks of 'worshippers of god' as those who 'have acquaintance with the rites of the gods' and who know 'how to serve the gods' ${ }^{50}$ What would take them by surprise would not be the epigraphic citation but rather the affirmation that this was not a new divinity for the Athenians to recognise, for they had already erected an altar to him. 51

Secondly, there would be no need for a herald to secure a parcel of land as a sacred site for this divinity because, as Paul asserts, he does not dwell in sanctuaries (vooi $\varsigma$ ) made with hands (17:24b). Furthermore no feasts would be required for him with the offering up of sacrifices, because he has no need of anything, since it is he who gives life and breath and all things to all of his creation (17:25).

50Diogenes Laertius, Zeno VII, 119. Much of the discussion as to whether there was or was not an inscription to a single god is misplaced. For further examples of the use of the singular and the plural in the same sentence and the discussion of this, see my 'In Public and in Private: Early Christians and Religious Pluralism' in A.D. Clarke and B.W. Winter (eds.), One God, One Lord: Christianity in a World of Religious Pluralism (Grand Rapids/Carlisle: Baker/Paternoster, 1992) 132-33. Paul is not, as Barnes suggests, 'using the sophistical trick of slightly misrepresenting the evidence in his own favour' ('An Apostle on Trial', 418).

${ }^{51}$ Barnes notes that 'Paul replies that his audience already acknowledges his God' ('An Apostle on Trial', 418), contra J. Dupont, Nouvelles Études sur les Actes des Apôtres (Paris: Cerf, 1984) 419-20. 
Whatever his hearers might have expected, this was no formal apologia for the admission of a new divinity for whom approval must be sought from the Demos on the recommendation of the Council. Paul asserts in 17:27 that this divinity 'is not far from each one of us', a statement confirmed in 17:28 by divinely inspired poets who know that 'in him we live and move and have our being' (e.g., Epimenides, the Cretan). There was hardly any need of a theophany if this was the case because the poets spoke with divine authority-'For we are also his offspring. ${ }^{\prime} 52$ Acts 17:28 rules out an inanimate configuration of a living and life-giving deity in terms 'of gold or silver, graven by art and device of man' (17:28-9).

This divinity could not therefore formally be introduced and added to the Pantheon of Athens, thereby sending a signal to all Macedonia and Achaea. He was not yet another god who should be acknowledged and added to the Pantheon. He was seeking something, but it was not authorisation from the legal entities in order to be admitted to Athens; instead, he was seeking repentance from them and from everyone, having already fixed the day of the assize, determined the ground rules for it, and appointed the judge for that purpose (17:30-31).

What proof was being offered? It was not an epiphany of the type usually sought, although had Paul finished his speech, he might have provided personal testimony of his own divine encounter, his epiphany on the road to Damascus (Acts $9: 5-6 ; 22: 6-11 ; 26: 12-18)$. Rather he cites the resurrection as the 'proof' of the coming judgement given by this deity given to all mankind. That some mocked Paul at this point is understandable, for the words said to have been cited at the Areopagus' dedication were 'When a man dies, the earth drinks up his

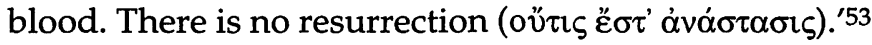

Those who had cast Paul in the traditional role of a herald would have realised from the speech itself that it was neither he nor his 'gods' who were seeking their official imprimatur. Rather the hearers were under investigation,

${ }^{52} \mathrm{Cf}$. Aratus, Phainomena 5 and Cleanthes, Hymn to Zeus 4.

${ }^{53}$ Aeschylus, Eumenides 647-48. 
including the Stoics and Epicureans who had improperly allowed their hearers to worship idols. ${ }^{54}$ The indictment that all were guilty before the God of heaven and earth was secured from the teaching of their own inspired poets. It was not an official authorisation that this divinity was seeking but their repentance in order to avoid the predetermined day of the great assize at the hands of the judge, the resurrected Jesus.

\section{The Wider Audience and the Areopagus Address}

The composition of those who heard Paul's address can be deduced in part from the narrative. We are told in 17:34 that 'some men believed', one of whom was Dionysius an Areopagite. In addition the woman, Damaris, is named 'and

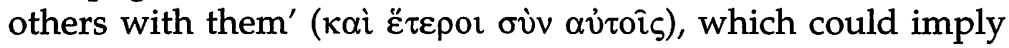
that they were members of the households of Dionysius and Damaris which in the case of the former possibly included clients who accompanied their patron in public.

More information can be deduced from Acts 17:21 which records: 'All the Athenians and foreigners who live there spend their time in nothing else, but either to tell or to hear some new thing.' While some have seen this verse as Luke's own comment 'on the Athenians' intellectual curiosity' and one that is 'clearly parenthetical', 55 it might instead serve to contrast their attitude with the seriousness of the last hearers of his message, the Bereans, who had treated it with 'all readiness of mind' (17:11). More likely, it is mentioned in order to clarify the outcome of the speech. That is, 17:21 contains the background information which later explains the diverse reaction of these Athenians and foreigners: some scoffed, while others appear to have suspended their judgement, saying 'We will hear you concerning this again' (17:32). While the sheer novelty of the resurrection accounts for a dismissive response on the part of some, the gospel did possess the power to win over others from

${ }^{54} \mathrm{On}$ the first century Stoic and Epicurean rapprochement with idolatry, see my 'Early Christians and Religious Pluralism', 138-40.

${ }^{55}$ Barnes adds: 'any argument based on its language is therefore irrelevant to what precedes and follows' ('An Apostle on Trial', 416). 
this audience (17:32). In spite of the proverbial attitude of Athenian audiences, Luke wished his readers to note that there were converts, apart from an Areopagite, as a result of the speech.

The presence of more than Areopagites is not surprising. From at least $487 \mathrm{BC}$, 'men of Athens' had played a role in the sanctioning of new deities.56 Any approval of Paul's teaching would finally be voted on by the Demos in their Ekklesia, if it were ever to reach that stage. However, they also had an important preliminary role in the introduction of new deities. Traditionally there had to be a ground swell of support for a new cult. Whatever may be said concerning the growing role of the Demos in the sanctioning of new gods after $487 \mathrm{BC}, 57$ it is clear that by Roman times the introduction of imperial gods had to have their sanction in addition to that of the Areopagus and the Council of 600 .

E. Haenchen's comment on 17:21 includes this claim: 'That it appears here as a motive precludes any sort of court proceedings-even a "merely informal one".'58 However, the above discussion by no means excludes a gathering of the Areopagus fulfilling its role by assessing the claims of Paul. Also in attendance were interested Athenians who were members of the Demos who would subsequently vote on a motion if the matter were to find its way on the agenda of its Ekklesia. Along with some interested resident aliens, they all gave a hearing to this divine 'herald' who declared those things which he maintained to be true.

\section{Conclusions}

R.W. Wallace, whose monograph discusses the Council of the Areopagus to $307 \mathrm{BC}$, sees that its legal competence for

56Garland, Introducing New Gods, 100.

57Garland, Introducing New Gods, 100.

${ }^{58} \mathrm{E}$. Haenchen, The Acts of the Apostles (ET: Oxford: Blackwell, 1971) 520. I.H. Marshall, Acts (Leicester: IVP, 1980) 285 sees it as 'a rare aside' by Luke, and C.J. Hemer, The Book of Acts in the Setting of Hellenistic History (Tübingen: J.C.B. Mohr [Paul Siebeck], 1989) 389 finds it to be the 'cutting edge of the raconteur's comment'. 
religious matters lay in the preservation of traditional piety. In the light of that he suggests that Paul in Acts 17:16-21, like the philosophers Stilpo and Theodoros in the fourth century BC, was summonsed to appear before them. ${ }^{59}$ That summons presupposes some 'impiety' ( $\alpha \sigma \varepsilon \dot{\beta} \varepsilon 1 \alpha$ ) which, according to Diogenes, was the case brought against these philosophers. 60 The above discussion has shown, however, that Paul was portrayed as being summonsed not for any wrong doing, but because he was seen as a herald whose claims were rightly to be assessed by the Areopagus, as Acts 17:18-20 suggests. ${ }^{61}$ Therefore this linking of Paul with Stilpo and Theodoros is incorrect. Rather Acts 17:18-20 is to be connected with the role of the Areopagus in examining the claim for introducing new deities into Athens.

According to Garland three things had to be demonstrated by the sponsor of a new religion in order to succeed with his cause in Athens: (1) the herald was the deity's representative, (2) the god was eager to set up residence in Athens, and (3) some benefit had already accrued to the Athenians which 'could be construed as proof ( $\mu \alpha \rho \tau$ viptov) or a sign ( $\sigma \eta \mu \varepsilon i ̂ v)$ of his goodwill.' 62 Paul, as an apostle, certainly fulfilled the first requirement (Acts 9:15). The people themselves had already erected an altar to this god and thereby had acknowledged his residence 'in Athens'. Moreover, 'proof' ( $\pi$ i $\sigma \tau \varsigma \varsigma$ ) of this deity's goodwill had been given not only to the Athenian people but to all mankind: a sign of his goodwill is evident in sending the seasons, and 'proof' of the assize is confirmed by the resurrection of Jesus. Even though this herald and his deity had fulfilled all these conditions for the introduction of a deity, the Athenians did not officially welcome Paul, or his deity. As Paul's speech unfolded, it soon

${ }^{59}$ Wallace, The Areopagus Council, 204-5, n. 88.

${ }^{60}$ Stilpon said that Athena was not a god but a goddess and Theodoros barely escaped appearing on an unspecified charge, Diogenes Laertius 2.101, 177.

61Wallace, The Areopagus Council, 106-12, 204-5. The role of recognising gods was different from that of the punishment of a person for the crime of asebeia,. which was also a function of that Council.

62Garland, Introducing New Gods, 19. 
became evident to his hearers that they could neither incorporate this god into the Pantheon nor officially endorse the view that idols contradicted the nature of deity, in spite of traditional Stoic and Epicurean teaching which supported this. According to Paul, this god needed nothing from them by way of a temple, or a festival day; instead, they depended totally on him, the one who alone gives life and breath to all.

Of course, not everyone would have heard the speech the same way. Stoics and Epicureans, for example, would have readily appreciated Paul's parallels with their understanding of natural theology, and would also have noted his point of departure from the received theology of the De natura deorum.63 With that said, however, aspects of the speech become clearer when the comment in 17:18 is seen to suggest that Paul appeared to be introducing foreign deities. The summary of the speech indicates that he was aware of this perception of himself and exploited it, claiming that he was not introducing new gods but declaring the nature of the God whose presence they had already recognised with the erection of an altar to him.

While Garland notes the poverty of extant evidence on the conventions surrounding the role of the Areopagus in introducing new gods in the period he covered, 64 important precedents can nevertheless be found from extant epigraphic sources in relation to the incorporation of the first-century imperial divinities into the Athenian Pantheon. Acts 17:18-20 also represents a small but crucial piece of information for ancient historians interested in the role of the Areopagus in the first century. 65 It depicts the formal role of the Areopagus, and provides a small window on its initial deliberations as it justifies its right to examine formally the new teaching by a promoter of 'foreign gods'.

\footnotetext{
${ }^{63}$ See my 'Early Christians and Religious Pluralism', 131, 136-40.

${ }^{64}$ Garland, Introducing New Gods, $18 \mathrm{ff}$.

${ }^{65} \mathrm{On}$ the general importance for ancient historians of this and other evidence from the New Testament corpus, see my 'Christentum und Antike: Acts and the Pauline Corpus as Ancient History' in Ancient History in a Modern University: Early Christianity and Late Antiquity (E.A. Judge Festschrift; Grand Rapids: Eerdmans, forthcoming 1996).
} 
Barnes reached a conclusion which he saw to be 'a negative one', viz. 'the possibility that Paul was actually tried by the Areopagus has not yet encountered adequate refutation. It is a further step (but a justifiable one) to assert that the possibility should be treated as a probability.' He also stated 'Paul's speech could be interpreted as a speech of defence to the charge of introducing a new religion to Athens.' 66 The above discussion has shown that it would be misleading to cast Paul in the role of a defendant in a trial in Acts 17, as was the case in Acts 24-26 where he appears before Roman judges. Rather, because some saw him as the herald of new gods, the Areopagus informed him of its legitimate role in this matter in Athens. It was appropriate that he should give account of his teaching before them since, as they claimed, 'We possess the right to judge what this new teaching is being spoken of by you. You are bringing "strange [foreign] things" to our ears: we therefore wish to judge what it is being claimed [or 'decreed'] "these things" are' (17:19-20).

66Barnes, 'An Apostle on Trial', 419. Some 130 years ago, W.L. Alexander, St. Paul at Athens (Edinburgh: Adam and Charles Black, 1865) 21 surmised: 'It was not, therefore, as charged with a crime that Paul was carried to the Areopagus, where the supreme court of Athens had its seat...It was... not anger... which brought Paul before it.' 